Web Jurnal:

http://ejournal.kemenperin.go.id/jli

\title{
Karakteristik konsentrasi timbel (Pb) dalam daun 3 (tiga) jenis pohon di sekitar pabrik peleburan aki bekas di Tangerang dan Bekasi
}

\section{Characteristics of lead $(P b)$ concentration in leaves of three tree species around used battery smelters in Tangerang and Bekasi}

\author{
Ridwan Fauzi*, Muhamad Yusup Hidayat, Bambang Hindratmo, dan Siti Masitoh \\ Pusat Penelitian Pengembangan Kualitas dan Laboratorium Lingkungan, \\ Kementerian Lingkungan Hidup dan Kehutanan \\ Kawasan Puspiptek Gedung 210, Serpong, Tangerang Selatan, Banten, Indonesia \\ * e-mail: ridwan_fkt@yahoo.com
}

\begin{tabular}{l}
\hline INFO ARTIKEL \\
\hline Sejarah artikel: \\
Diterima: \\
21 Februari 2019 \\
Direvisi: \\
27 November 2019 \\
Diterbitkan: \\
30 Desember 2019
\end{tabular}

\section{Kata kunci:}

timbel $(\mathrm{Pb})$;

peleburan;

aki bekas;

kawasan industri

\begin{abstract}
ABSTRAK
Konsentrasi timbel $(\mathrm{Pb})$ yang tinggi di udara, khususnya di sekitar pabrik peleburan aki bekas berisiko bagi kesehatan manusia. Tumbuhan mempunyai fungsi filtrasi terhadap polutan udara sehingga udara yang dihasilkan menjadi lebih segar. Peran tumbuhan dalam penyerapan timbel di lokasi sekitar peleburan aki bekas belum banyak dikaji. Penelitian ini bertujuan mengidentifikasi karakteristik konsentrasi timbel dalam daun di sekitar pabrik peleburan aki bekas di kawasan industri Kadu Manis Tangerang dan kawasan industri Jababeka Bekasi. Penelitian ini adalah penelitian kuantitatif, sampel yang diambil merupakan daun pada pohon yang berada di sekitar kawasan industri Kadu Manis Tangerang dan kawasan industri Jababeka Bekasi. Sampel daun diambil sesuai arah mata angin dengan jenis pohon yang diambil adalah Trembesi (Samanea saman), Bintaro (Cerbera manghas), dan Glodokan (Polyalthia longifolia). Sampel daun diambil dalam radius 0 hingga 7,5 km dari lokasi peleburan aki bekas. Konsentrasi timbel dalam daun dihitung dengan menggunakan AAS (Atomic Absorption Spectrophotometry). Analisis data dilakukan dengan menggunakan regresi linear berganda. Hasil penelitian menunjukkan bahwa arah angin berpengaruh nyata terhadap konsentrasi timbel dalam daun. Pepohonan yang berada di sebelah utara pabrik peleburan mempunyai kadar timbel paling besar dibanding tiga arah lainnya. Jarak dengan peleburan aki bekas hanya berpengaruh nyata terhadap konsentrasi timbel di kawasan industri Jababeka Bekasi.
\end{abstract}

Keywords:

lead $(\mathrm{Pb})$;

smelter;

used batteries;

industrial area

\begin{abstract}
The high concentration of lead $(\mathrm{Pb})$ in the air, especially around the smelter of used batteries is harmful for human health. Plants have a good filtration function for air pollutants. Effect of plants in the absorption of lead in the air, especially in locations around the smelting of used batteries has not been widely studied. This study aims to identify the characteristics of lead concentration in leaves around the smelter in industrial area of Kadu Manis, Tangerang and industrial area of Jababeka, Bekasi. This research is quantitative research, samples taken are leaves on trees that are around the smelters. Leaf samples were taken following the direction of the wind, with the tree species taken were Trembesi (Samanea saman), Bintaro (Cerbera manghas), and Glodokan (Polyalthia longifolia). Samples were taken in a radius of 0 to $7.5 \mathrm{~km}$ from the smelters. The lead concentration was analyzed using AAS (Atomic Absorption Spectrophotometry). Data analysis was performed using multiple linear regression. Wind direction has a significant effect on lead concentration in leaves. Trees that are north of the smelter have the highest lead levels compared to the other three directions. The distance with lead smelting only has a significant effect on lead concentration in Jababeka Industries.
\end{abstract}




\section{Pendahuluan}

Logam berat yang terbuang sebagai akibat aktivitas anthropogenic ke udara menjadi polutan yang bisa membahayakan bagi kehidupan. Seperti logam timbel $(\mathrm{Pb})$ diketahui ada di dalam semua keadaan di alam, baik dalam tanah, sungai, danau, dan dalam laut (Sanna and Vallascas, 2011). Meskipun logam timbel adalah logam yang cukup berat, logam timbel juga ditemukan di udara, sebagai komponen pada debu dan uap air laut yang berhembus (Samsoedin et al., 2015)..

Logam timbel adalah unsur beracun dan berbahaya bagi kesehatan manusia bahkan pada tingkat yang relatif rendah (Samsoedin et al., 2015). Salah satu paparan timbel pada manusia adalah melalui sistem pernafasan, sekitar $25-50 \%$ timbel akan diserap oleh paru-paru karena ukurannya yang kecil $(<0,5 \mu \mathrm{m})$ sehingga lebih mudah diserap oleh jaringan paru-paru dan sisanya akan tertahan oleh rambut di hidung (Eibensteiner et al., 2005; Feleafel and Mirdad, 2013; Hindratmo et al., 2018). Bahkan timbel yang masuk dalam jaringan darah akan menyebabkan penyakit hipertensi (Ambarwanto et al., 2016).

Timbel merupakan salah satu polutan yang dihasilkan oleh aktivitas pembakaran bahan bakar minyak kendaraan bermotor dan aktivitas penguraian baik melalui pembakaran maupun secara alami bahanbahan yang mengandung logam timbel (Sanna and Vallascas, 2011; Santoso et al., 2012). Daerah Kabupaten Tangerang yang terdapat pabrik peleburan aki bekas juga menunjukkan logam timbel di udara ambien yang cukup tinggi yaitu mencapai $2,045 \mu \mathrm{g} / \mathrm{m}^{3}$. Nilai ini lebih tinggi dari baku mutu yang telah ditetapkan yaitu hanya $2 \mu \mathrm{g} / \mathrm{m}^{3}$ (Mukhtar et al., 2013). Selain konsentrasi pencemaran timbel di udara ambien yang di atas baku mutu, juga ditemukan konsentrasi timbel dalam darah anak usia sekolah di sekitar kawasan pabrik peleburan aki di Kabupaten Tangerang juga cukup tinggi. Konsentrasi rata-rata timbel dalam darah anak usia sekolah tersebut mencapai $32,0 \mu \mathrm{g} / \mathrm{dL}$. Nilai ini juga sudah di atas baku mutu yang telah ditetapkan oleh World Health Organization (WHO) yaitu $5 \mu \mathrm{g} / \mathrm{dL}$ (Hindratmo et al., 2018).

Konsentrasi timbel yang tinggi di sekitar kawasan industri yang mendaur ulang aki bekas untuk pemurnian timbel kerap memberikan dampak buruk bagi udara di sekitarnya. Timbel dapat dengan mudah terdistribusi melalui media udara dari cerobong-cerobong yang terdapat di pabrik peleburan aki bekas (Brik and Ben Ammar, 2013). Kondisi ini mengakibatkan kualitas udara di sekitar pabrik menjadi tercemar oleh partikelpartikel timbel. Kawasan industri yang di dalamnya terdapat aktivitas peleburan timbel harus memperhatikan konsep pembangunan berkelanjutan dengan memperhatikan salah satunya fungsi tumbuhan sebagai filtrasi alami untuk polutan-polutan di udara yang dihasilkan dari pabrik tersebut. Kemampuan tumbuhan dalam menyaring polutan udara yang berimbas pada udara yang dihasilkan lebih segar (Pratiwi, 2012).

Konsentrasi timbel di udara dapat dikendalikan dengan menggunakan tumbuhan untuk menjerap dan menyerap timbel di udara (Hidayat et al., 2019; Istiaroh et al., 2014). Sehingga tumbuhan bertindak sebagai agen fitoremidiasi logam timbel (Caroline and Moa, 2015; Ferdhiani et al., 2015). Fungsi tumbuhan sebagai agen hayati tersebut bermanfaat untuk mereduksi polutan timbel di udara, hal ini menjadikan pentingnya suatu penelitian untuk mengetahui secara detail peran tersebut. Penelitian ini bertujuan untuk mengidentifikasi karakteristik konsentrasi timbel dalam daun di sekitar pabrik peleburan aki bekas yang berada di kawasan industri Kadu Manis Tangerang dan kawasan industri Jababeka Bekasi.

\section{Metode}

Pengumpulan data penelitian dilaksanakan di sekitar pabrik peleburan aki bekas di Kabupaten Tangerang, Propinsi Banten dan Kabupaten Bekasi, Propinsi Jawa Barat pada bulan Mei sampai dengan Juli 2018. Sedangkan analisis konsentrasi $\mathrm{Pb}$ dilakukan di Laboratorium Pusat Penelitian Pengembangan Kualitas dan Laboratorium Lingkungan (P3KLL), Serpong, Tangerang Selatan pada bulan Mei sampai dengan November 2018.

Pengambilan sampel berupa daun dari jenis pohon yang berada di sekitar pabrik. Sampel daun pohon diambil dari 3 jenis pohon yang ada di sekitar pabrik peleburan aki bekas. Ada beberapa kriteria daun yang diambil sebagai sampel, yaitu:

a) Jenis pohon yang diambil sampelnya dari 3 jenis pohon yang sama. Jenis pohon yang diambil daunnya yaitu Trembesi (Samanea saman), Glodokan (Polyalthia longifolia), dan Bintaro (Cerbera manghas).

b) Lokasi pengambilan pohon dengan sumber pencemar/ pabrik pada 3 titik yang berbeda secara random dengan batasan jarak dari sumber pencemar. Pembagian jarak pengambilan pohon sampel yaitu jarak $0-2,5 \mathrm{~km} ; 2,5-5 \mathrm{~km}$; dan $5-7,5 \mathrm{~km}$. Jalur pengambilan sampel mempertimbangkan empat arah angin.

c) Pengambilan daun di pohon dibagi dalam 3 bagian tajuk yaitu tajuk atas, tajuk tengah, dan tajuk bawah. Posisi daun yang di ambil berdasarkan arah mata angin yaitu utara, selatan, barat, dan timur). Jumlah daun yang diambil setiap arah mata angin sebanyak 5-10 helai untuk kemudian didekomposit dalam satu pohon.

Teknik pengambilan sampel daun diambil dari pohon secara acak, masing-masing dikumpulkan dalam kantong plastik dan dianalisis di laboratorium untuk dihitung konsentrasi timbelnya. Konsentrasi timbel ditentukan berdasarkan berat kering daun dengan 2 ulangan sampel untuk analisis logam timbel berasal dari daun pohon. Analisis timbel dalam daun pada kegiatan pengembangan ini menggunakan Intruksi Kerja (IK04/B/P3KLL tahun 2014) merujuk pada metode APHA 2012 dengan menggunakan AAS (Atomic Absorption Spectrophotometry) (Hidayat et al., 2019). 


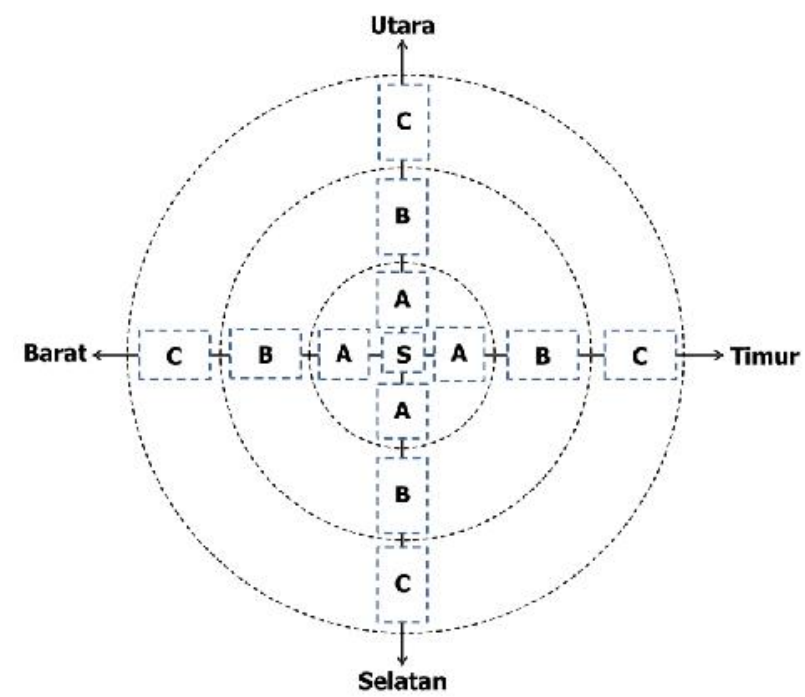

Keterangan:

- A,B,C, dan D merupakan area pengambilan sampel (panjang setiap jalur $\pm 2,5 \mathrm{~km}$ ).

- S merupakan sumber polutan (lokasi pabrik peleburan aki bekas)

Gambar 1. Sketsa pengambilan sampel daun berdasarkan arah angin.

Analisis data dilakukan dengan membandingkan terhadap konsentrasi logam timbel dalam daun dengan konsentrasi logam timbel dalam daun jenis pohon lainnya. Data konsentrasi timbel dalam daun yang diambil diolah secara kuantitatif dengan menggunakan perhitungan statistika. Pengaruh jarak pohon dengan sumber pencemar, jenis pohon, dan arah angin lokasi pohon terhadap konsentrasi dianalisis dengan menggunakan analisis regresi linier berganda (multiple linear regression). Formulasi yang disusun dalam analisis konsentrasi timbel dalam daun sebagai berikut:

$$
\begin{aligned}
\text { Kons }_{\mathrm{i}}= & \beta_{0}+\beta_{1} \text { Jarak }_{\mathrm{i}}+\beta_{2} \text { Diameter }_{\mathrm{i}}+\beta_{3} \text { Tinggi }_{\mathrm{i}} \\
& +\beta_{4} \mathrm{LAI}_{\mathrm{i}}+\varepsilon_{\mathrm{i}}
\end{aligned}
$$

\section{Keterangan:}

$\begin{aligned} \text { Kons }_{\mathrm{i}}= & \text { konsentrasi timbel di daun ke } \mathrm{i}(\mathrm{ppm}), \\ \text {Jarak}_{\mathrm{i}}= & \text { jarak sampel daun ke i dengan sumber } \\ & \text { pencemar }(\mathrm{km}), \\ \text { Diameter }_{\mathrm{i}}= & \text { diameter pohon ke } \mathrm{i}(\mathrm{cm}), \\ \text { Tinggi }_{\mathrm{i}}= & \text { tinggi pohon ke } \mathrm{i}(\mathrm{m}), \\ \mathrm{LAI}_{\mathrm{i}}= & \text { Leaf Area Index jenis i (Hidayat et al., } \\ & 2019 ; \text { the Singapore Botanic Gardens, } \\ & \text { 2013), } \\ \beta_{0} & \text { nilai konstanta dari model, } \\ \beta_{1}, \beta_{2}, \ldots, \beta_{4}= & \text { koefisien regresi dari masing-masing } \\ & \text { variabel, } \\ \varepsilon_{\mathrm{i}} & \text { erorr term dari model. }\end{aligned}$

\section{Hasil dan pembahasan}

Penelitian ini melakukan pengambilan data konsentrasi timbel dalam daun dari beberapa jenis tanaman yang berada di sekitar kawasan peleburan aki bekas. Lokasi pengambilan sampel daun dilakukan di 2 (dua) lokasi, yaitu sekitar pabrik peleburan aki bekas di Kawasan Industri Kadu Manis, Kabupaten Tanggerang dan sekitar peleburan aki bekas di Kawasan Industri Jababeka, Kabupaten/Kota Bekasi. Penelitian ini menggunakan sampel yang diambil dari bagian tumbuhan berupa daun karena daun sebagai bagian tumbuhan yang paling berperan dalam proses evapotranspirasi atau keluar masuknya partikel ke dalam bagian tumbuhan. Selain itu daun merupakan bagian tumbuhan yang paling dahulu terpapar polutan di udara (Istiaroh et al., 2014).

Pengambilan sampel daun dilakukan terhadap 3 (tiga) jenis tanaman. Ketiga jenis tersebut adalah Trembesi (Samanea saman), Glodokan (Polyalthia longifolia), dan Bintaro (Cerbera manghas). Pohonpohon tersebut banyak ditemukan di turus jalan. Lokasi pengambilan sampel ditentukan berdasarkan interval jarak dengan lokasi peleburan aki bekas. Interval jarak yang digunakan yaitu $0-2,5 \mathrm{~km},>2,5-5 \mathrm{~km}$, dan $>5-$ 7,5 km dari industri peleburan aki bekas. Di setiap lokasi/ interval jarak diambil sampel daun dari ketiga jenis pohon tersebut. Sehingga, jumlah sampel yang berhasil dikumpulkan di lapangan sebanyak 36 sampel daun dari 3 jenis pohon. Selain pengambilan sampel daun juga dilakukan perekaman koordinat lokasi, diameter pohon, dan tinggi pohon.

\subsection{Kawasan Industri Kadu Manis Kabupaten Tangerang}

Di sekitar kawasan industri Kadu Manis, Kabupaten Tangerang pengambilan sampel dilakukan pada Bulan Mei 2018. Sampel yang berhasil dikumpulkan sebanyak 36 sampel daun dari 3 jenis pohon. Sampel-sampel tersebut diambil secara random pada 4 arah penjuru mata angin. letak sampel secara lebih jelas bisa dilihat di Gambar 1.

Sampel daun yang telah diambil dilakukan analisis untuk mengetahui konsentrasi timbel. Analisis pengujian konsentrasi timbel dilakukan di Laboratorium P3KLL, Serpong. Pengujian konsentrasi timbel dilakukan di Laboratorium P3KLL, Serpong. Laboratorium telah terakreditasi dengan nomor akreditas LP 083 IDN. Pengujian konsentrasi timbel dilakukan dengan menggunakan IK-04/B/P3KLL tahun 2014. Hasil pengujian tersaji dalam Tabel 1 dengan konsentrasi timbel hasil pengujian tertera di kolom 4 .

Berdasarkan Tabel 1 dapat dilihat nilai konsentrasi timbel dalam daun tertinggi adalah pada jenis pohon trembesi (Samanea saman) dengan konsentrasi timbel terkandung sebesar 44,98 $\mathrm{mg} / \mathrm{kg}$ dan berada di sebelah timur dari pabrik peleburan aki bekas. Nilai konsentrasi timbel terkecil adalah jenis Bintaro (Cerbera manghas) dengan konsentrasi timbel $0,33 \mathrm{mg} / \mathrm{kg}$ dengan lokasi sebelah timur dari pabrik peleburan. Rata-rata konsentrasi timbel dalam daun di sekitar kawasan peleburan aki bekas adalah 12,23 $\mathrm{mg} / \mathrm{kg}$. Dengan ratarata konsentrasi timbel berdasarkan lokasi arah dari peleburan yang tertinggi yaitu disebelah utara pabrik peleburan mencapai 20,37 mg/kg. Penelitian yang dilakukan oleh Samsoedin et al. (2015) menemukan konsentrasi timbel dalam daun pada beberapa jenis pohon di Tangerang adalah 3,30-101,93 $\mathrm{ppm} / \mathrm{cm}^{2}$. 


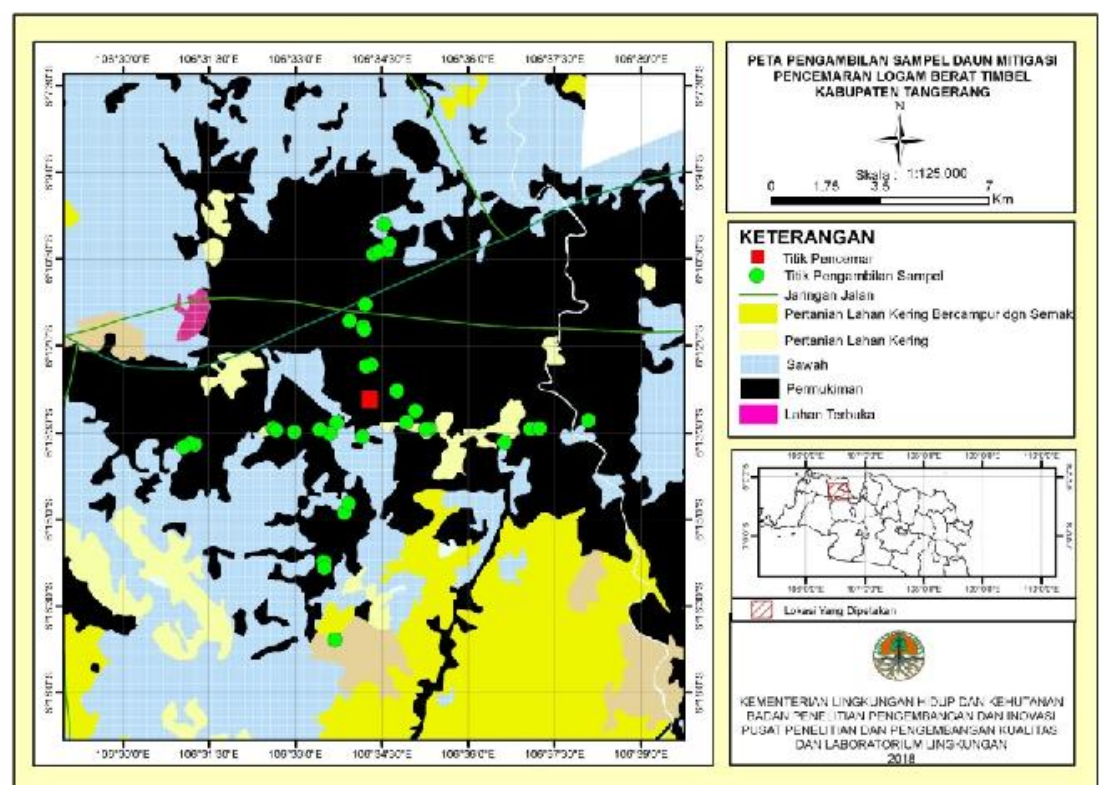

Gambar 1. Peta lokasi pengambilan sampel daun di wilayah sekitar industri Kadu Manis, Kabupaten Tangerang.

Tabel 1.

Konsentrasi timbel dalam daun dari beberapa pohon di sekitar kawasan industri Kadu Manis, Kabupaten Tangerang.

\begin{tabular}{|c|c|c|c|c|c|c|c|}
\hline Arah & Nama Pohon & Range & $\begin{array}{l}\text { Konsentrasi } \\
(\mathrm{mg} / \mathrm{kg})\end{array}$ & LAI & $\begin{array}{l}\text { Jarak ke } \\
\text { Sumber }\end{array}$ & Diameter & Tinggi \\
\hline \multirow{9}{*}{ Barat } & \multirow{3}{*}{ 1. Bintaro (Cerbera manghas) } & 1 & 7,42 & 4 & 1,22 & 8 & 5 \\
\hline & & 2 & 8,57 & 4 & 3,22 & 30 & 12 \\
\hline & & 3 & 5,27 & 4 & 5,92 & 8 & 6 \\
\hline & \multirow[t]{3}{*}{ 2. Glodokan (Polyalthia longifolia) } & 1 & 10,39 & 3 & 1,17 & 5 & 3 \\
\hline & & 2 & 4,32 & 3 & 3,14 & 15 & 10 \\
\hline & & 3 & 3,47 & 3 & 5,77 & 5 & 2 \\
\hline & \multirow[t]{3}{*}{ 3. Trembesi (Samanea saman) } & 1 & 20,82 & 2,5 & 1,8 & 35 & 17 \\
\hline & & 2 & 24,66 & 2,5 & 2,6 & 50 & 20 \\
\hline & & 3 & 4,88 & 2,5 & 6,2 & 15 & 10 \\
\hline \multirow[t]{9}{*}{ Selatan } & \multirow[t]{3}{*}{ 1. Bintaro (Cerbera manghas) } & 1 & 13,04 & 4 & 0,66 & 20 & 8 \\
\hline & & 2 & 4,67 & 4 & 3,14 & 17 & 6 \\
\hline & & 3 & 4,23 & 4 & 5,1 & 30 & 12 \\
\hline & \multirow{3}{*}{ 2. Glodokan (Polyalthia longifolia) } & 1 & 5,78 & 3 & 1,48 & 20 & 14 \\
\hline & & 2 & 3,95 & 3 & 3,15 & 8 & 5 \\
\hline & & 3 & 3,40 & 3 & 7,17 & 12 & 17 \\
\hline & \multirow[t]{3}{*}{ 3. Trembesi (Samanea saman) } & 1 & 22,85 & 2,5 & 0,06 & 32 & 15 \\
\hline & & 2 & 16,16 & 2,5 & 2,81 & 32 & 16 \\
\hline & & 3 & 9,01 & 2,5 & 5,1 & 20 & 14 \\
\hline \multirow[t]{9}{*}{ Timur } & \multirow[t]{3}{*}{ 1. Bintaro (Cerbera manghas) } & 1 & 4,65 & 4 & 1,66 & 25 & 13 \\
\hline & & 2 & 0,33 & 4 & 4,29 & 15 & 10 \\
\hline & & 3 & 0,72 & 4 & 5,32 & 25 & 9 \\
\hline & \multirow[t]{3}{*}{ 2. Glodokan (Polyalthia longifolia) } & 1 & 14,12 & 3 & 1,26 & 15 & 9 \\
\hline & & 2 & 1,53 & 3 & 4,26 & 7 & 5 \\
\hline & & 3 & 0,68 & 3 & 5,32 & 35 & 20 \\
\hline & \multirow[t]{3}{*}{ 3. Trembesi (Samanea saman) } & 1 & 10,16 & 2,5 & 1,2 & 40 & 11 \\
\hline & & 2 & 6,98 & 2,5 & 4,27 & 28 & 15 \\
\hline & & 3 & 44,98 & 2,5 & 5,32 & 35 & 20 \\
\hline \multirow[t]{9}{*}{ Utara } & \multirow[t]{3}{*}{ 1. Bintaro (Cerbera manghas) } & 1 & 22,13 & 4 & 1,72 & 15 & 7 \\
\hline & & 2 & 10,57 & 4 & 2,96 & 10 & 8 \\
\hline & & 3 & 13,91 & 4 & 5,34 & 10 & 6 \\
\hline & \multirow[t]{3}{*}{ 2. Glodokan (Polyalthia longifolia) } & 1 & 36,29 & 3 & 1,72 & 20 & 14 \\
\hline & & 2 & 23,62 & 3 & 2,96 & 15 & 12 \\
\hline & & 3 & 7,41 & 3 & 5,63 & 18 & 10 \\
\hline & \multirow[t]{3}{*}{ 3. Trembesi (Samanea saman) } & 1 & 13,89 & 2,5 & 1,69 & 25 & 8 \\
\hline & & 2 & 28,60 & 2,5 & 2,87 & 30 & 12 \\
\hline & & 3 & 26,90 & 2,5 & 5,4 & 10 & 4 \\
\hline \multicolumn{2}{|l|}{ Rata-rata } & & 12,23 & & & & \\
\hline
\end{tabular}


Penelitian yang dilakukan oleh Inayah et al (2010) menunjukkan bahwa rata-rata konsentrasi timbel yang terdapat pada tanaman Angsana yang ada di kota Tanggerang berkisar antara 2,04 - 7,30 $\mu \mathrm{g} / \mathrm{g}$. Partikel logam berat yang menempel pada permukaan daun yang lebih lebar dan lebih kasar adalah tujuh kali lebih besar daripada permukaan daun yang licin (Santoso et al., 2012). Permukaan daun yang licin dan lurus apabila terpapar debu partikel yang menempel akan mudah tertiup angin sehingga waktu tinggalnya lebih sebentar, sehingga penyerapan timbal ke dalam daunnya lebih sedikit (Dewi, 2012).

\section{Tabel 2.}

Hasil estimasi faktor-faktor mempengaruhi konsentrasi timbel dalam daun pada pohon sekitar pabrik peleburan aki bekas di kawasan industri Kadu Manis, Kabupaten Tangerang.

\begin{tabular}{llll}
\hline Variabel & Koefisien & $\begin{array}{l}\text { Standard } \\
\text { Error }\end{array}$ & Sig. \\
\hline $\begin{array}{l}\text { Jarak Pohon dengan } \\
\text { Sumber }\end{array}$ & $-1,304$ & 0,825 & \\
\hline Arah angin & $-4,371$ & 1,348 & $* * *$ \\
\hline Diameter pohon & 0,091 & 0,228 & \\
\hline Tinggi Pohon & 0,651 & 0,517 & \\
\hline Leaf Area Index & $-4,025$ & 2,513 & \\
\hline (Constant) & 31,528 & 10,366 & $* * *$ \\
\hline Jumlah Obs & 36 & & \\
\hline Signifikansi Model & $* * *$ & & \\
\hline$R$ Square & 0,451 & & \\
\hline Adjusted $R$ Square & 0,360 & & \\
\hline Keterangan: & & \\
$* * *:$ Signifikan $\alpha=1 \%$ & & \\
\hline
\end{tabular}

Berdasarkan hasil estimasi dengan menggunakan analisis regresi berganda untuk mengetahui faktor-faktor yang mempengaruhi konsentrasi timbel dalam daun pada pohon di sekitar kawasan industri Kabupaten Tangerang dapat dilihat pada hasil estimasi Tabel 2. Hasil estimasi menunjukkan bahwa konsentrasi timbel di daun hanya dipengaruhi oleh arah sumber. Setelah ditelusur lebih mendalam konsentrasi timbel paling besar berada di sebelah utara kawasan industri Kadu Manis. Pada kegiatan penelitian yang dilakukan oleh (Hermawan et al., 2011; Hidayat et al., 2019) menunjukkan pola bahwa jarak berpengaruh secara signifikan terhadap konsentrasi timbel dalam daun. Pada penelitian tersebut, sumber polutan merupakan timbel yang berasal dari kendaraan bermotor. Namun demikian, dengan hasil penelitian ini dapat diduga adanya sumber lain pencemaran timbel selain yang bersumber dari kawasan industri Kadu Manis. Karakteristik pencemaran timbel di udara mengikuti arah angin dan jarak, apabila sumber pencemar sudah diketahui maka konsentrasi timbel akan semakin kecil apabila semakin jauh dari sumber pencemar (Bobu et al., 2013).

Berdasarkan Tabel 3 dapat dijelaskan bahwa konsentrasi timbel pada daun di sekitar kawasan industri Kadu Manis berbeda nyata secara statistik. Hal ini ditunjukkan dengan signifikansi hasil analisis pada tingkat kepercayaan 95\% $(\mathrm{P}<0,05)$. Dari tabel tersebut konsentrasi timbel di sebelah utara kawasan industri berbeda nyata dengan 3 arah yang lain, yaitu barat, selatan, dan timur.
Tabel 3.

Hasil estimasi konsentrasi timbel dalam daun berdasarkan arah sumber pencemar dari kawasan industri Kadu Manis di Kabupaten Tangerang.

\begin{tabular}{lllll}
\hline Arah & Arah & Koefisien & $\begin{array}{l}\text { Standar } \\
\text { Error }\end{array}$ & Sig. \\
\hline Utara & Barat & 10,39111 & 4,69187 & $* *$ \\
& Selatan & 11,13667 & 4,69187 & $* *$ \\
& Timur & 11,01889 & 4,69187 & $* *$ \\
\hline Barat & Utara & $-10,39111$ & 4,69187 & $* *$ \\
& Selatan & 0,74556 & 4,69187 & \\
& Timur & 0,62778 & 4,69187 & \\
\hline Selatan & Utara & $-11,13667$ & 4,69187 & $* *$ \\
& Barat & $-0,74556$ & 4,69187 & \\
& Timur & $-0,11778$ & 4,69187 & \\
\hline Timur & Utara & $-11,01889$ & 4,69187 & $* *$ \\
& Barat & $-0,62778$ & 4,69187 & \\
& Selatan & 0,11778 & 4,69187 & \\
\hline
\end{tabular}

Keterangan:

$*$ : Signifikan $\alpha=5 \%$

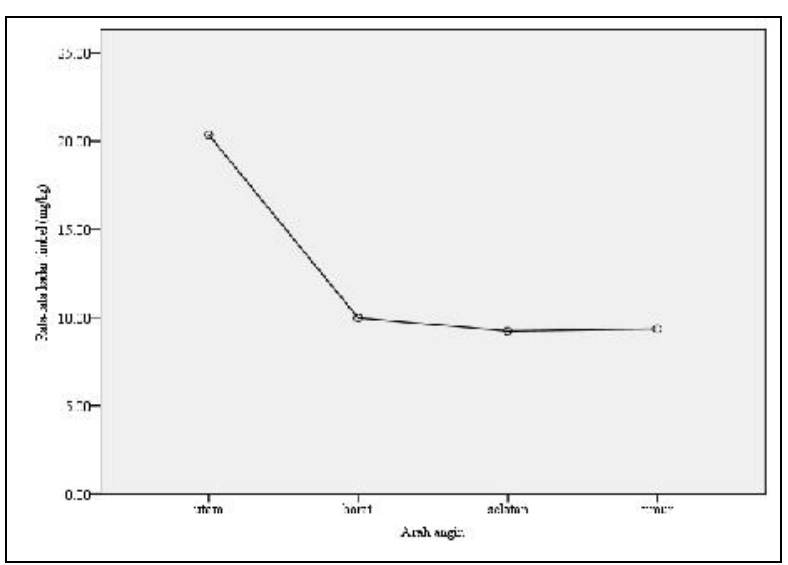

Gambar 2. Rata-rata konsentrasi timbel dalam daun pada pohon sekitar kawasan industri Kabupaten Tangerang berdasarkan arah sumber.

Secara rata-rata konsentrasi timbel dari sampel daun yang diambil di sebelah utara kawasan industri lebih tinggi. Nilai ini bisa dilihat pada Gambar 2, konsentrasi timbel di sebelah utara kawasan industri pada nilai ratarata antara $18-21 \mathrm{mg} / \mathrm{kg}$. Lebih detail rata-rata konsentrasi timbel di sebelah utara adalah $20,37 \mathrm{mg} / \mathrm{kg}$, sebelah barat adalah $9,98 \mathrm{mg} / \mathrm{kg}$, sebelah selatan adalah $9,23 \mathrm{mg} / \mathrm{kg}$, dan sebelah timur adalah $9,35 \mathrm{mg} / \mathrm{kg}$.

\subsection{Kawasan Industri Jababeka Bekasi}

Pengambilan sampel di kawasan industri Jababeka Bekasi dilakukan pada Bulan Juli 2018. Pengambilan sampel dilakukan selama dua hari dengan sampel yang berhasil dikumpulkan sebanyak 36 sampel daun.

Berdasarkan hasil analisis pengujian konsentrasi timbel dari sampel yang diambil tersaji di Tabel 4. Pengembangan ini mendapat temuan bahwa konsentrasi timbel pada daun di pohon sekitar kawasan industri Jababeka Bekasi paling besar adalah 91,028 mg/kg. Konsentrasi timbel ini ditemukan dari tanaman bintaro (Cerbera manghas) pada jarak 60 meter dari pabrik peleburan aki bekas. Lokasi pohon bintaro tersebut berada di sebelah utara dari pabrik peleburan. Konsentrasi timbel pada daun paling rendah yaitu 0,018 $\mathrm{mg} / \mathrm{kg}$ yang berada di sebelah timur pabrik peleburan dan berjarak 2,71 km dari pabrik peleburan. Jenis pohon 
tersebut adalah glodokan (Polyalthia longifolia). Ratarata konsentrasi timbel dalam daun di pohon-pohon sekitar kawasan industri Jababeka Bekasi adalah 5,810 $\mathrm{mg} / \mathrm{kg}$. Konsentrasi timbel dalam daun di wilayah Bekasi berdasarkan temuan (Samsoedin et al., 2015) adalah $12,04-98,21 \mathrm{~g} / \mathrm{cm}^{2}$.

Tabel 4.

$\underline{\text { Konsentrasi timbel dalam daun dari beberapa pohon di Kabupaten/Kota Bekasi. }}$

\begin{tabular}{|c|c|c|c|c|c|c|c|}
\hline Arah & Nama Pohon & Interval & $\begin{array}{l}\text { Konsentrasi } \\
(\mathrm{mg} / \mathrm{kg})\end{array}$ & LAI & $\begin{array}{l}\text { Jarak ke } \\
\text { Sumber }\end{array}$ & Diameter & Tinggi \\
\hline \multirow[t]{9}{*}{ Barat } & \multirow[t]{3}{*}{ 1. Bintaro (Cerbera manghas) } & 1 & 1,903 & 4 & 2,26 & 10 & 4 \\
\hline & & 2 & 5,850 & 4 & 3,77 & 15 & 4 \\
\hline & & 3 & 2,390 & 4 & 6,81 & 12 & 4 \\
\hline & \multirow[t]{3}{*}{ 2. Glodokan (Polyalthia longifolia) } & 1 & 1,592 & 3 & 1,27 & 20 & 15 \\
\hline & & 2 & 2,390 & 3 & 4,42 & 14 & 15 \\
\hline & & 3 & 1,178 & 3 & 6,81 & 13 & 10 \\
\hline & \multirow{3}{*}{ 3. Trembesi (Samanea saman) } & 1 & 2,233 & 2,5 & 1,27 & 15 & 8 \\
\hline & & 2 & 2,344 & 2,5 & 4,42 & 30 & 15 \\
\hline & & 3 & 3,085 & 2,5 & 6,81 & 15 & 6 \\
\hline \multirow[t]{9}{*}{ Selatan } & \multirow[t]{3}{*}{ 1. Bintaro (Cerbera manghas) } & 1 & 0,795 & 4 & 2,09 & 20 & 7 \\
\hline & & 2 & 1,207 & 4 & 4,28 & 17 & 7 \\
\hline & & 3 & 0,806 & 4 & 6,66 & 23 & 6 \\
\hline & \multirow[t]{3}{*}{ 2. Glodokan (Polyalthia longifolia) } & 1 & 0,397 & 3 & 2,09 & 20 & 12 \\
\hline & & 2 & 1,212 & 3 & 4,28 & 7 & 4 \\
\hline & & 3 & 1,503 & 3 & 6,66 & 32 & 8 \\
\hline & \multirow[t]{3}{*}{ 3. Trembesi (Samanea saman) } & 1 & 5,885 & 2,5 & 2,09 & 40 & 13 \\
\hline & & 2 & 1,503 & 2,5 & 4,28 & 40 & 15 \\
\hline & & 3 & 2,649 & 2,5 & 5,91 & 32 & 10 \\
\hline \multirow[t]{9}{*}{ Timur } & \multirow[t]{3}{*}{ 1. Bintaro (Cerbera manghas) } & 1 & 1,590 & 4 & 0,57 & 37 & 15 \\
\hline & & 2 & 1,196 & 4 & 2,71 & 30 & 8 \\
\hline & & 3 & 0,365 & 4 & 6,11 & 25 & 6 \\
\hline & \multirow[t]{3}{*}{ 2. Glodokan (Polyalthia longifolia) } & 1 & 3,925 & 3 & 0,57 & 20 & 17 \\
\hline & & 2 & 0,018 & 3 & 2,71 & 23 & 16 \\
\hline & & 3 & 1,969 & 3 & 4,6 & 12 & 7 \\
\hline & \multirow[t]{3}{*}{ 3. Trembesi (Samanea saman) } & 1 & 1,141 & 2,5 & 0,67 & 50 & 20 \\
\hline & & 2 & 1,208 & 2,5 & 2,71 & 17 & 8 \\
\hline & & 3 & 1,149 & 2,5 & 4,6 & 30 & 7 \\
\hline \multirow[t]{9}{*}{ Utara } & \multirow[t]{3}{*}{ 1. Bintaro (Cerbera manghas) } & 1 & 91,028 & 4 & 0,06 & 10 & 7 \\
\hline & & 2 & 2,398 & 4 & 2,73 & 18 & 8 \\
\hline & & 3 & 0,807 & 4 & 6,49 & 25 & 12 \\
\hline & \multirow[t]{3}{*}{ 2. Glodokan (Polyalthia longifolia) } & 1 & 4,776 & 3 & 0,38 & 20 & 11 \\
\hline & & 2 & 2,607 & 3 & 2,73 & 15 & 7 \\
\hline & & 3 & 1,886 & 3 & 5,73 & 20 & 14 \\
\hline & \multirow[t]{3}{*}{ 3. Trembesi (Samanea saman) } & 1 & 48,651 & 2,5 & 0,06 & 35 & 14 \\
\hline & & 2 & 4,786 & 2,5 & 2,73 & 30 & 15 \\
\hline & & 3 & 0,753 & 2,5 & 6,49 & 40 & 15 \\
\hline Rata-rata & & & 5,810 & & & & \\
\hline
\end{tabular}

Berdasarkan hasil estimasi faktor-faktor yang mempengaruhi konsentrasi timbel dalam daun di sekitar kawasan industri Jababeka, Bekasi dengan menggunakan analisis regresi berganda tersaji dalam Tabel 5. Hasil estimasi menunjukkan bahwa perubahan variabel dependen dapat dijelaskan dengan variabel jarak sampel dengan industri, arah sampel, diameter pohon sampel, tinggi pohon sampel, dan leaf area index. Nilai $\mathrm{R}$ kuadrat sebesar 0,311 menunjukkan bahwa 31,1 persen perubahan konsentrasi timbel pada daun masih bisa dijelaskan dari variabel-varibel tersebut. Sisanya yaitu 69,9 persen dijelaskan dari variabel-variabel di luar variabel tersebut. Namun demikian, model tersebut masih bisa digunakan untuk mengestimasi faktor-faktor yang mempengaruhi konsentrasi timbel dalam daun $(\mathrm{P}<$ $0,05)$.
Tabel 5.

Hasil estimasi faktor-faktor yang mempengaruhi konsentrasi timbel dalam daun pada pohon sekitar pabrik peleburan aki bekas di kawasan industri Jababeka, Bekasi.

\begin{tabular}{llll}
\hline Variabel & Koefisien & $\begin{array}{l}\text { Standard } \\
\text { Error }\end{array}$ & Sig. \\
\hline $\begin{array}{l}\text { Jarak Pohon dengan } \\
\text { Sumber }\end{array}$ & $-3,489$ & 1,219 & $* * *$ \\
\hline Arah Sumber & $-5,426$ & 2,315 & $* *$ \\
\hline Diameter pohon & 0,159 & 0,333 & \\
\hline Tinggi Pohon & $-0,872$ & 0,857 & \\
\hline Leaf Area Index & 1,255 & 4,592 & \\
\hline Konstanta & 33,167 & 21,445 & \\
\hline Jumlah Sampel & 36 & & \\
\hline Signifikansi model & $* *$ & & \\
\hline$R$ Square & 0,311 & \\
\hline Adjusted $R$ Square & 0,197 & \\
\hline $\begin{array}{l}\text { Keterangan: } \\
* * *\end{array} \quad$ Signifikan $\alpha=1 \%$ \\
$\quad:$ Signifikan $\alpha=5 \%$
\end{tabular}




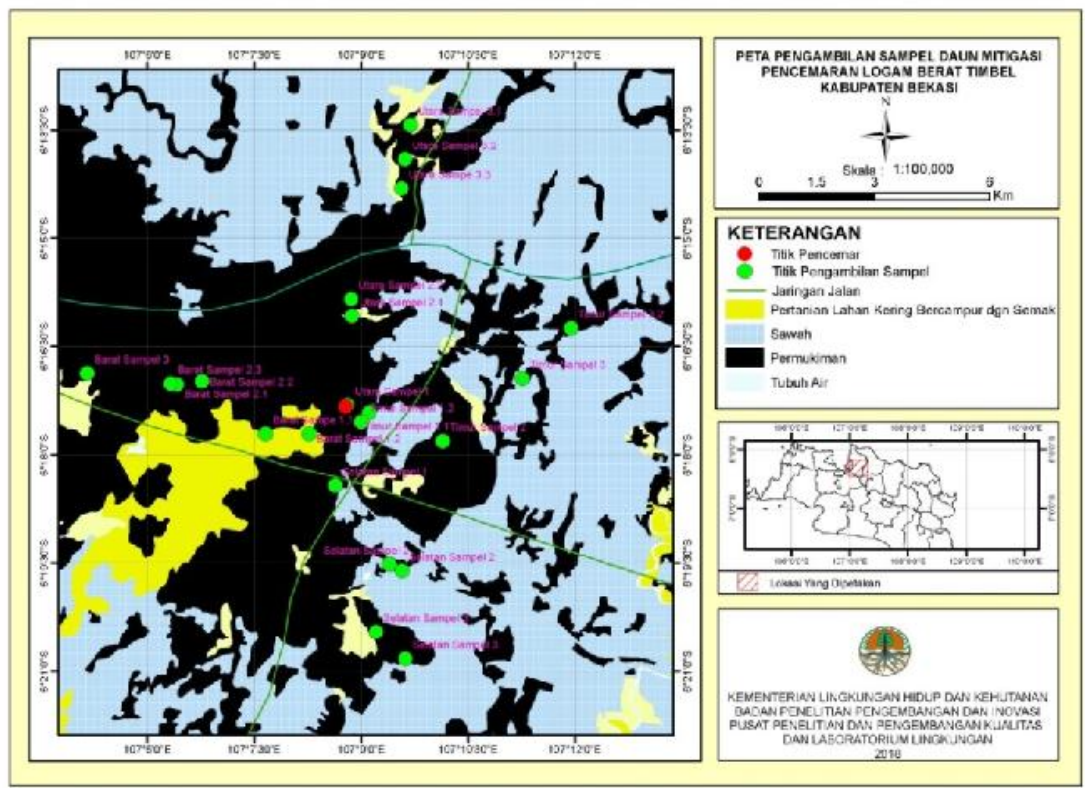

Gambar 3. Peta lokasi pengambilan sampel daun di wilayah sekitar industri Jababeka, Bekasi.

Variabel jarak pohon dengan sumber pencemar menunjukkan hasil signifikan pada tingkat kepercayaan 99 persen $(\mathrm{P}<0,01)$. Nilai ini dapat di interpretasikan bahwa setiap kenaikan jarak dari sumber pencemar satu satuan $(\mathrm{km})$, maka akan mengurangi konsentrasi timbel dalam daun $3,49 \mathrm{mg} / \mathrm{kg}$ dengan catatan variabel yang lain konstan/ tetap. Hal tersebut sejalan dengan penelitian yang dilakukan oleh (Hermawan et al., 2011) bahwa jarak pohon menentukan konsentrasi timbel dalam daun. Semakin jauh jarak pohon dengan sumber pencemar maka konsentrasi timbel dalam daun akan semakin kecil. Selain itu, lokasi sampel berdasarkan arah dari kawasan industri juga berpengaruh signifikan pada tingkat kepercayaan 95 persen $(\mathrm{P}<0,05)$.

Tabel 6.

Hasil estimasi konsentrasi timbel dalam daun berdasarkan arah sumber pencemar dari kawasan industri di Kabupaten/Kota Bekasi.

\begin{tabular}{lllll}
\hline $\begin{array}{l}\text { Arah } \\
\text { angin }\end{array}$ & $\begin{array}{l}\text { Arah } \\
\text { angin }\end{array}$ & Koefisien & $\begin{array}{l}\text { Standard } \\
\text { error }\end{array}$ & Sig. \\
\hline Utara & Barat & 14,969667 & 7,453484 & $*$ \\
& Selatan & 15,748333 & 7,453484 & $* *$ \\
& Timur & 16,125667 & 7,453484 & $* *$ \\
\hline Barat & Utara & $-14,969667$ & 7,453484 & $*$ \\
& Selatan & 0,778667 & 7,453484 & \\
& Timur & 1,156000 & 7,453484 & \\
\hline Selatan & Utara & $-15,748333$ & 7,453484 & $* *$ \\
& Barat & $-0,778667$ & 7,453484 & \\
& Timur & 0,377333 & 7,453484 & \\
\hline Timur & Utara & $-16,125667$ & 7,453484 & $* *$ \\
& Barat & $-1,156000$ & 7,453484 & \\
& Selatan & $-0,377333$ & 7,453484 & \\
\hline Keterangan: & & & \\
$*$ : Signifikan $\alpha=10 \%$ & & \\
$* *$ : Signifikan $\alpha=5 \%$ & & & \\
\hline
\end{tabular}

Berdasarkan Tabel 6 dapat dijelaskan bahwa lokasi sampel berdasarkan arah dari kawasan industri Jababeka berpengaruh signifikan terhadap konsentrasi timbel dalam daun. Konsentrasi timbel dalam daun yang berada di sebelah utara kawasan industri paling besar. Hal tersebut terbukti secara statistik bahwa sampel yang berada di sebelah utara kawasan industri mempunyai nilai konsentrasi timbel pada daun lebih besar, dibandingkan dengan sebelah barat, selatan, dan timur.

Berdasarkan arah lokasi pengambilan sampel ditemukan rata-rata konsentrasi timbel paling besar berada pada sampel-sampel yang diambil sebelah utara kawasan industri Jababeka, yaitu mencapai 17,52 mg/kg. Sementara itu, yang berada di sebelah barat, selatan, dan timur masing-masing adalah 2,55 mg/kg, 1,77 mg/kg, dan $1,40 \mathrm{mg} / \mathrm{kg}$. Konsentrasi timbel pada daun yang berada di jarak 0-2,5 km menunjukkan hasil yang paling tinggi yaitu $13,66 \mathrm{mg} / \mathrm{kg}$. Pada jarak $>2,5-5 \mathrm{~km}$ ditemukan konsentrasi timbel pada daun sebanyak 2,23 $\mathrm{mg} / \mathrm{kg}$, dan pada jarak >5-7,5 km konsentrasi timbel dalam daun didapat sebanyak $1,55 \mathrm{mg} / \mathrm{kg}$. Secara grafik bisa dilihat pada Gambar 4.

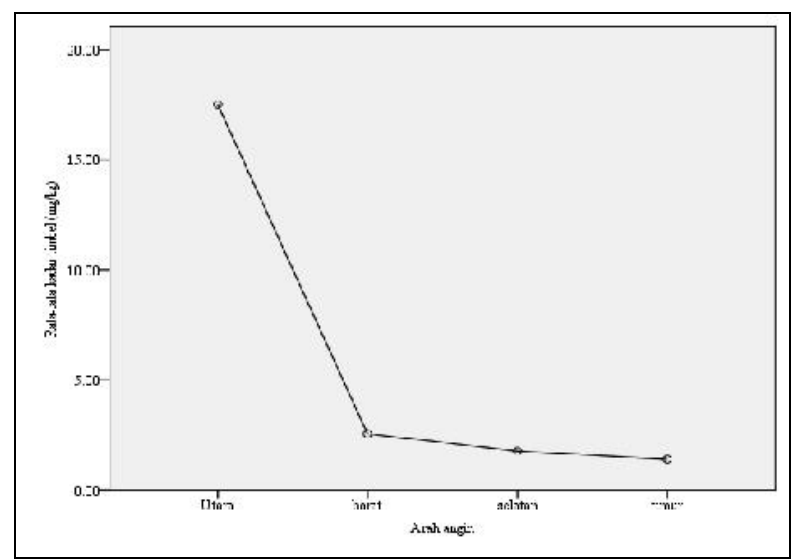

Gambar 4. Rata-rata konsentrasi timbel dalam daun pada pohon sekitar kawasan industri Kabupaten Bekasi berdasarkan arah sumber. 
Apabila melihat faktor-faktor yang berpengaruh terhadap konsentrasi timbel dalam daun untuk wilayah Jababeka Bekasi berbeda dengan wilayah industri Kadu Manis Tangerang. Pada karakteristik faktor-faktor yang mempengaruhi konsentrasi timbel dalam daun di wilayah industri Kadu Manis, variabel jarak tidak berpengaruh signifikan secara statistik terhadap konsentrasi timbel. Kondisi ini dimungkinkan ada sumber lain yang berasal dari peleburan aki bekas ilegal yang masih beroperasi. Keadaan tersebut mengakibatkan variabel jarak tidak berpengaruh signifikan terhadap konsentrasi timbel dalam di kawasan industri Kadu Manis.

\section{Kesimpulan}

Lokasi pohon berpengaruh terhadap konsentrasi timbel dalam daun pada pohon di sekitar kawasan peleburan aki bekas. Pohon-pohon yang berada di sebelah utara kawasan peleburan cenderung mempunyai konsentrasi timbel lebih besar dibandingkan pohonpohon yang berada di sebelah barat, selatan, dan timur. Tindakan mitigasi dengan melakukan penanaman pohon sebagai pereduksi timbel di udara. akan lebih berdampak optimal apabila mempertimbang arah angin.

\section{Ucapan terima kasih}

Penulis mengucapkan terimakasih kepada tim penelitian "Mitigasi Dampak Pencemaran Udara Dalam Darah Pada Anak Sekolah Tahun 2018”, Pusat Penelitian Pengembangan Kualitas dan Laboratorium Lingkungan (P3KLL) atas dukungan pendanaan dalam pengambilan dan analisis data penelitian, dan kepada semua pihak yang terlibat dalam penulisan dan penyusunan jurnal ini.

\section{Daftar pustaka}

Ambarwanto, S.T., Nurjazuli, N., Raharjo, M., 2016. Hubungan paparan timbal dalam darah dengan kejadian hipertensi pada pekerja industri pengecoran logam di Ceper Klaten tahun 2015. J. Kesehat. Lingkung. Indones. 14, 35-39. https://doi.org/ 10.14710/jkli.14.2.35 - 39

Bobu, F.R., Noor, J.A.E., Bunawas, B., 2013. Pengukuran konsentrasi timbal $(\mathrm{Pb})$ dalam debu di rumah penduduk kawasan Desa Kadu, Kecamatan Curug, Tangerang - Banten. Brawijaya Phys. Student J. 1, 1-6.

Brik, K., Ben Ammar, F., 2013. Causal tree analysis of depth degradation of the lead acid battery. J. Power Sources 228, 39-46. https://doi.org/10.1016/ j.jpowsour.2012.10.088

Caroline, J., Moa, G.A., 2015. Fitoremediasi logam timbal $(\mathrm{Pb})$ menggunakan tanaman melati air (Echinodorus palaefolius) pada limbah industri peleburan tembaga dan kuningan, in: Seminar Nasional Sains Dan Teknologi Terapan III. pp. 733744.

Dewi, Y.S., 2012. Kajian efektifitas Daun Puring (Codiaeum Variegatum) dan Lidah Mertua (Sansevieria trispasciata) dalam menyerap timbal di udara ambien. J. Ilm. Univ. Satya Negara Indones.
Vol.5, 1-7.

Eibensteiner, L., Sanz, A.D.C., Frumkin, H., Gonzales, C., Gonzales, G.F., 2005. Lead exposure and semen quality among traffic police in Arequipa, Peru. Int. J. Occup. Environ. Health 11, 161-166. https://doi.org/10.1179/oeh.2005.11.2.161

Feleafel, M.N., Mirdad, Z.M., 2013. Hazard and effects of pollution by lead on vegetable crops. J. Agric. Environ. Ethics 26, 547-567. https://doi.org/ 10.1007/s10806-012-9403-1

Ferdhiani, A.A., Lestari, S., Proklamasiningsih, E., 2015. Aktivitas enzim peroksidase dan kadar klorofil pada daun Angsana (Pterocarpus indicus) sebagai peneduh jalan yang terpapar timbal. J. Biosf. 32, 126-133.

Hermawan, R., Kusmana, C., Nasrullah, N., Prasetyo, L.B., 2011. Jerapan debu dan partikel timbal $(\mathrm{Pb})$ oleh daun berdasarkan letak pohon dan posisi tajuk: studi kasus jalur hijau Acacia mangium, jalan Tol Jagorawi. Media Konserv. 16, 101-107.

Hidayat, M.Y., Fauzi, R., Hindratmo, B., 2019. Konsentrasi timbel $(\mathrm{Pb})$ pada daun dari beberapa jenis pohon di sekitar kawasan industri Kadu Manis, Tangerang. J. Penelit. Kehutan. Wallacea 8, 19-25.

Hindratmo, B., Rahmani, R., Rita, 2018. Kadar timbel dalam darah siswa sekolah dasar di sekitar peleburan aki bekas di Kabupaten Tangerang dan Lamongan. J. Ecolab 12, 93-101.

Inayah, S.N., Las, T., Yunita, E., 2010. Kandungan Pb pada daun Angsana (Pterocarpus indicus) dan Rumput Gajah Mini (Axonopus.Sp) di jalan protokol Kota Tangerang. J. Val. 2, 340-346.

Istiaroh, P.D., Martuti, N.K.T., Bodijanto, F.P.M.H., 2014. Uji kandungan timbal $(\mathrm{Pb})$ dalam daun tanaman peneduh di jalan protokol Kota Semarang. Biosaintifika 6, 60-66.

Mukhtar, R., Wahyudi, H., Hamonangan, E., Lahtiani, S., Santoso, M., Lestiani, D.D., Kurniawati, S., 2013. Kandungan logam berat dalam udara ambien pada beberapa kota di Indonesia. Ecolab 7, 49-59.

Pratiwi, S.R., 2012. Mempengaruhi kesadaran masyarakat dalam mengatasi polusi udara (timbal / $\mathrm{Pb})$ di Kota Tarakan, Provinsi Kalimantan Timur. J. Bisnis dan Ekon. Ef. 3, 77-86.

Samsoedin, I., Dharmawan, I.W.S., Pratiwi, Wahyono, D., 2015. Peran pohon dalam menjaga kualitas udara di perkotaan, 1st ed. FORDA PRESS (Anggota IKAPI), Bogor, Jawa Barat.

Sanna, E., Vallascas, E., 2011. Hair lead levels to evaluate the subclinical impact of lead on growth in Sardinian children (Italy). Am. J. Hum. Biol. 23, 740-746. https://doi.org/10.1002/ajhb.21203

Santoso, S., Lestasi, S., Samiyarsih, S., 2012. Inventarisasi tanaman peneduh jalan penjerap timbal di Purwokerto, in: Seminar Pengembangan Sumber Daya Pedesaan Dan Kearifan Lokal Berkelanjutan II. Universitas Jenderal Soedirman, Purwokerto, Jawa Tengah, pp. 978-979.

The Singapore Botanic Gardens, 2013. Flora Fauna Web - Plant Detail - Samanea saman (Jacq.) Merr. [WWW Document]. Flora Fauna Natl. Park. URL https://florafaunaweb.nparks.gov.sg/Special-Pages/ plant-detail.aspx $\mathrm{id}=3106$ (accessed 5.21.19). 